\title{
THE IMPACT OF DEFERRED TAX ASSETS, DISCRETIONARY ACCRUAL, LEVERAGE, COMPANY SIZE AND TAX PLANNING ONEARNINGS MANAGEMENT PRACTICES
}

\section{Jacobus Widiatmoko ${ }^{\bowtie}$, Ika Mayangsari}

Faculty of Economics and Bussiness, Stikubank University, Semarang, Indonesia

Info Article

History Article:

Received October 2015

Approved January 2016

Published March 2016

\section{Keywords:}

Deferred Tax Asset; Discretion-

ary Accrual, Leverage; Company

Size; Tax Planning; and Earnings

Management

\begin{abstract}
The purpose of this study is to analyze and provide empirical evidence of the influence of deferred tax asset, discretionary accrual, leverage, company size, and tax planning on earnings management. Financial performance is an indicator that is required by company management to measure the effectiveness of company performance. This research used secondary data that was got from annual report published in www.idx.co.id and data from Indonesian Capital Market Directory (ICMD). Populations of the research are manufacturing companies listed on Indonesia Stock Exchange from 2011-2013. Samples were selected by using purposive sampling method. There are 208 observations that will examined by logistic regression analysis. The result shows that deferred tax asset has negative and not significant effect to the earnings management, discretionary accrual has negative and not significant effect to the earnings management, leverage has negative and significant effect to the earnings management, company size has positive and significant effect to the earnings management, tax planning has positive and not significant effect to the earnings management.
\end{abstract}

\section{PENGARUH ASET PAJAK TANGGUHAN, DISCRETIONARY ACCRUAL, LEVERAGE, UKURAN PERUSAHAAN, DAN PERENCANAAN PAJAK TERHADAP PRAKTIK MANAJEMEN LABA}

\begin{abstract}
Abstrak
Tujuan penelitian ini menganalisis bukti empiris mengenai pengaruh asset pajak tangguhan, discretionary accrual, leverage, ukuran perusahaan, dan perencanaan pajak terhadap manajemen laba. Kinerja keuangan adalah indikator untuk mengukur efektivitas perusahaan. Penelitian ini menggunakan data sekunder yang diperoleh dari www.idx.co.id serta data dari Indonesian Capital Market Directory (ICMD). Populasi penelitian ini adalah perusahaan manufaktur yang terdaftar di BEI tahun 2011-2013. Sampel dipilih dengan purposive sampling. Terdapat 208 observasi yang akan diuji dengan model analisis regresi logistik. Hasil penelitian ini menunjukkan bahwa asset pajak tangguhan memiliki pengaruh negatif dan tidak signifikan terhadap praktik manajemen laba, discretionary accrual memiliki pengaruh negatif dan tidak signifikan terhadap praktik manajemen laba, leverage memiliki pengaruh negatif dan signifikan terhadap praktik manajemen laba, ukuran perusahaan memiliki pengaruh positif dan signifikan terhadap praktik manajemen laba, perencanaan pajak memiliki pengaruh positif dan tidak signifikan terhadap praktik manajemen laba.
\end{abstract}

JEL Classification: G3, G32 
Jacobus Widiatmoko \& Ika Mayangsari / The Impact of Deferred Tax Assets...

\section{INTRODUCTION}

Financial performance of a company describes financial condition and progress in achieving the company's goal. Financial performance of a company illustrates financial condition that is analyzed using financial analysis tools so it can be identified how good and bad of financial condition of a company is which reflects the performance in certain period. It shows that financial performance is an indicator that is required by company management to measure the effectiveness of company performance. Besides, financial performance is an indicator that will be used by investors before doing investment. Many things become a benchmark performance of a company, one of which is the company's ability to generate profits. (Mao \& Renneboog, 2015; Wu et al, 2016)

The importance of earnings information for the users of financial statements requires the earnings information, which reflects the actual condition of economy and finance. However, the manager, who is responsible for making financial statement, often pervert the authority to do earning value manipulation for obtaining some private gain. The action to manipulate earning value in financial statement of a company is called earning management. It is used by manager as a way to show a good performance in gaining maximum profit for the company and try to give positive impression for investors.

Doing earning management does not only depend on the amount of debt, company size and company growth, but also it is caused that company wants to influence short-term market's performance. (Xie et al, 2003; Iatridis 2012). Efforts to manipulate earnings information by managers is done by manipulating components in the financial statements, either by changing the size of profit and to hide or delay the disclosure of certain components.

Earnings management action is not merely the fault of management. This is because Financial Accounting Standard (IFRSs) allows management to choose various alternative of accounting method to manage company's profit.
However, it cannot be denied that this manipulation makes the financial statement being irrelevance to take economy decision. It is caused that information in earning value has been adjusted with manager's interest (Jao \& Pagalung, 2011).

The earning value manipulation, which is done by management, is hard to detect by users of financial statement. Whereas, this management action can bring negative impact to all sort of parties. Therefore, financial statement users should have understanding and knowledge about various indicators that can predict manager to do earning management. As a result the possibility of false financial statement can be noticed. Some earning management predictors are deferred tax assets, discretionary accrual (Wu et al, 2016), leverage , company size, and tax planning (Dewi \& Fenny, 2011; Ulfah, 2013; Riantani \& Nurzamzam, 2015).

Deferred tax assets are defined as amount of income tax that can be restored in the next period. It is caused by temporary difference, accumulation of taxlosseshas not been compensated and accumulation of tax credit has not been used in which tax rules allow it. (SFAS No46 in Juni 2012). PSAK No. 46 also states that the value of deferred tax assets should be reviewed in the end of each reporting period, so it give chance for management to review and determine new value of deferred tax assets, which is subjective. (Suranggane, 2007).

The study done by Widiastuti and Chusniah (2011) found that deferred tax assets have positive and significant influence on earning management. However, the study of Suranggane (2007), Dewi and Fenny (2011), and Pindiharti (2011), conclude that deferred tax assets have negative and not significant influence on earning management.

SFAS No. 1 about Financial Statement Presentation should put an entity in making financial statement based on accrual concept, except cash flow statement. The concept of accrual can be divided into two, namely discretionary accrual and nondiscretionary accrual. Discretionary accrual is the recognition of accrued in- 
come or expense that are free, are not regulated and the selection of management policies (Pindiharti, 2011), while nondiscretionary accrual is the recognition accrual reasonable profit and subject to the standard or generally accepted accounting principles (Subagyo et al, 2011). Discretionary accrual can be made through the selection of accounting policies related to accrual but it is subjective and contextual.

Research Suranggane (2007), Widiastuti and Chusniah (2011), concluded that there is a significant positive effect on earnings management of discretionary accruals. However, different results shown from other researchers. Results of research conducted by Dewi and Fenny (2011), as well as Subagyo et al (2011) show that discretionary accruals are not significant positive effect on earnings management.

Leverage is the degree of the use of debt as a source of corporate financing. The higher the leverage means the company has a greater debt than capital or assets of the company, so that managers attempt to increase company profits to give a positive signal to investors and creditors.

The influence of leverage variable on earnings management has been investigated by Aryani (2011) who found that the leverage has positively and significant influence to earnings management. Research result of Dewi and Fenny (2011) also found a positive effect of leverage on earnings management, but not significantly. However, research of Jao and Pagalung (2011) showed different results, which leverage has insignificant negative effect on earnings management.

Companies with a relatively large size, especially monopolist or which controlling public needs of many people, usually have a high political cost because it becomes subject of government and public observation. Watts and Zimmerman (1986) suggest that the large companies which have a high political cost is more likely to choose the method of accounting to reduce reported earnings compared to small companies. Investigation on the size of the company conducted by Han and Wong (1998),
Field et al, (2001), Dewi and Fenny (2011) which concluded that the the size of the company has significant and positive effect on earnings management. Ulfah (2013) also found that the the size of the company has a positive effect but not significant to earnings management. Meanwhile, different results are found by Aryani (2011), as well as Jao and Pagalung (2011) which concluded the the size of the company has significant and negative effect on earnings management.

Tax planning related to manipulation process of business and transactions the taxpayer is done to make the tax debt in minimal amounts, but it is still within tax regulations. However, tax planning can also be interpreted as planning of tax obligations fulfillment completely, correctly, and on time so it can optimally avoid waste of resources (Ulfah, 2013). This tax planning will give chance for managers to lower the value of earnings in order to make the tax imposed on company become smaller.

Research conducted by Subagyo and Oktavia (2010) concluded that tax planning has a positive and significant influence to earnings management, especially in a company that experienced profits (profit firms). However, different results shown by Ulfah (2013) as well as Aditama and Purwaningsih (2013) who found similar results that there is not significant and positive effect of tax planning on company earnings management practices.

Inconsistent result of research motivates to re-investigate the effect of deferred tax assets, discretionary accrual, leverage, company size, and tax planning to earnings management practices.

\section{Hypothesis Development}

Earnings management is the current behavior by managers to raise or lower the profit in the process of external financial reporting in order to benefit himself (Belkaoui, 2007). Managers manipulate earnings value in the financial statements because the earnings value is considered reflecting the performance of management in a period, so it needs to 
Jacobus Widiatmoko \& Ika Mayangsari / The Impact of Deferred Tax Assets...

be modified for the interests of the manager. Earnings management is used by manager as a means to demonstrate its good performance in generating maximum profits for the company and try to give a positive signal to investors.

\section{Deferred Tax Assets and Earnings Manage- ment}

Positive difference between accounting profit and fiscal profit makes positive correction resulting deferred tax assets (Surranggane, 2007). Deferred tax assets are recognized in all temporary difference that is allowed to reduce, as long as those possibilities of big temporary difference can be used to decrease fiscal profits in the future. SFAS No. 46 states that states that the value of deferred tax assets should be reviewed in the end of each reporting period, so it gives chance for management to review and determine new value of deferred tax assets, which is subjective.

Flexibility of deferred tax asset valuation conducted by management will provide an opportunity for managers to manipulate these values for its own sake. It is in line with agency theory which states that managers will act as an agent to maximize his needs. The higher value of deferred tax assets, the lower the tax debt in the future. Then, it will ultimately improve the company's profit in the future, so managers will be having a good assessment by the principal and obtain compensation for the performance. This reasoning is consistent with research of $\mathrm{Wi}$ diastuti and Chusniah (2011) that found that the deferred tax assets have a significant positive effect on earnings management. Based on the above, the hypothesis is formulated as follows.

H1:Deferred Tax Assets has positive effect on earning management action.

\section{Discretionary Accrual and Earnings Mana- gement}

The manager seeks to give a positive signal by presenting high profit value, so as to attract investors and ultimately shows the performance of a good manager. One effort to increase the value of profits is to manipulate earnings through discretionary accrual. Therefore, there is a positive relationship between discretionary accruals and earnings management. This is as same as research of Suranggane (2007), Cohen et al (2008), Widiastuti and Chusniah (2011), Linck et al (2013) concluded that there is a significant positive effect between discretionary accrual to earnings management. Based on the above, the hypothesis is formulated as follows

$\mathrm{H} 2$ :Discretionary accrual has positive effect on earning management practices

\section{Leverage and Earnings Management}

The leverage ratio may indicate risks faced by the company, because of the greater risks faced by the company, the uncertainty of future profitability will also increase. Debt covenants hypothesis in a positive accounting theory states that companies with high debt levels will tend to choose accounting policies that can increase the profit value to avoid violating debt covenant. Therefore, managers will attempt to increase company profits to give a positive signal to investors and creditors to cover high degree of leverage.

This management effort can be in the form of earnings management practices to manipulate the value of earnings to make it look high. Abiprayu and Pangestuti (2011), Jao and Pagalung (2011), Dewi and Fenny (2011) found that the leverage has a significant positive effect on earnings management. Based on the above, the hypothesis is formulated as follows.

$\mathrm{H} 3$ :Leverage has positive effect on earnings management practices

\section{Company Size and Earnings Management}

The political cost hypothesis in a positive accounting theory states that the size of the company is used as a guide for political costs and for political costs will increase with the size and risk of the company. Companies with a relatively large size usually have a high political cost because it becomes subject of government and public observation. Watts and Zimmerman 
(1986) suggest that the large companies which have a high political cost is more likely to choose the method of accounting for reducing reported earnings. Research of Dewi and Fenny (2011) concluded that the size of the company has significant and positive effect on earnings management. Based on the above, the hypothesis is formulated as follows.

H4:Company Size has positive effect on earnings management practices.

\section{Tax Planning and Earnings Management}

Efforts to minimize the tax burden is often called the tax planning or tax sheltering (Suandy, 2013). The political cost hypothesis in a positive accounting theory states that the company is trying to avoid large political costs, for example the tax burden, the higher tax value, the lower the profits to be obtained. Research Subagyo and Oktavia (2010), Ulfah (2013), Aditama and Purwaningsih (2013), concluded that tax planning has a significant positive effect on earnings management. Based on the above, the hypothesis is formulated as follows

H5: Tax Planning has positive effect on earnings management practices

\section{METHOD}

\section{Population and Sample}

The population in this research is manufacturing companies listed on the Stock Exchange in 2011-2013. The data uses secondary data from the financial statements of manufacturing companies of www.idx.co.id and ICMD 2013. Samples were selected using purposive sampling technique, it is manufacturing companies listing in a row on the Stock Exchange in 2011-2013, published financial statements denominated in rupiah which has the final period on December 31 , and having complete information related to all the variables studied.

\section{Operational Definition and Measurement of Variables}

\section{Earnings Management}

Earnings Management in this research was measured using formula that has been used by Philips et al (2003), Subagyo et al (2011), and Aditama and Purwaningsih (2013) as follows.

$$
\mathrm{EM}=\frac{\mathrm{NI}_{\mathrm{it}}-\mathrm{NI}_{\mathrm{it}-1}}{\mathrm{MVE}_{\mathrm{it}-1}}
$$

Explanation:

$\mathrm{EM}=$ Earnings management

$\mathrm{NI}_{\text {it }} \quad$ = Net income of companyiyear $\mathrm{t}$

$\mathrm{NI}_{\text {it-1 }}^{\text {it }}$ = Net income companyiyear $\mathrm{t}-1$

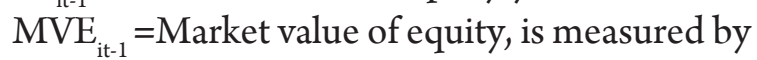
multiplying the company's current s tock price by its number of outstanding shares.

If $\mathrm{EM} \geq 0$, company is considered doing earning management and will be given the number of 1 . Whereas if $\mathrm{EM}<0$, companies is considered not doing earnings management and will be given the number of 0 .

\section{Deferred Tax Assets}

Deferred tax assets are measured from the change of the value of deferred tax assets divided by the value of deferred tax assets at end of period t (Suranngane 2007; Dewi \& Fenny 2011; Widiastuti \& Chusniah 2011; Pindiarti 2011).

$$
\mathrm{CAPT}_{\mathrm{it}}=\frac{\Delta \text { Deferred Tax Assets }_{\mathrm{it}}}{\text { Deferred Tax Assets }_{\mathrm{it}}}
$$

\section{Discretionary Accrual}

Discretionary accrual was calculated using Modified Jones Model (1991), which was also used by Suranngane (2007); Dewi \& Fenny (2011); Widiastuti \& Chusniah (2011). Calculating accrual value :

$$
\mathrm{TAcc}_{\mathrm{it}}=\mathrm{NI}_{\mathrm{it}}-\mathrm{CFO}_{\mathrm{it}}
$$

Total accrual was estimated using OLS regression equation 
Jacobus Widiatmoko \& Ika Mayangsari / The Impact of Deferred Tax Assets...

$$
\begin{aligned}
\frac{\operatorname{TAcc}_{i t}}{\mathrm{~A}_{i t-1}}= & \beta_{1}\left(\frac{1}{\mathrm{~A}_{i t-1}}\right)+\beta_{2}\left(\frac{\Delta \mathrm{SALES}_{i t}}{\mathrm{~A}_{i t-1}}-\frac{\Delta \mathrm{AR}_{i t}}{\mathrm{~A}_{i t-1}}\right) \\
& +\beta_{3}\left(\frac{\mathrm{PPE}_{i t}}{\mathrm{~A}_{i t-1}}\right)+\mathrm{e}
\end{aligned}
$$

Calculating value of nondiscretionary accrual using this formula:

$$
\begin{aligned}
\mathrm{NDA}_{i t}= & \beta_{1}\left(\frac{1}{\mathrm{~A}_{i t-1}}\right)+\beta_{2}\left(\frac{\Delta \mathrm{SALES}_{i t}}{\mathrm{~A}_{i t-1}}-\frac{\Delta \mathrm{AR}_{i t}}{\mathrm{~A}_{i t-1}}\right) \\
& +\beta_{3}\left(\frac{\mathrm{PPE}_{i t}}{\mathrm{~A}_{i t-1}}\right)
\end{aligned}
$$

Calculating value of discretionary accrual:

$$
\mathrm{DA}_{i t}=\left(\frac{\mathrm{TAcc}_{i t}}{\mathrm{~A}_{i t-1}}-\mathrm{NDA}_{i t}\right)
$$

Explanation:

TAcc $_{\text {it }}=$ Total of company accrual in the period of $\mathrm{t}$

$\mathrm{NDA}_{\mathrm{it}}=$ Non-discretionary accrual of company in the period of $t$

$\mathrm{DA}_{\mathrm{it}}=$ Discretionary accrual of company in the period of $\mathrm{t}$

$\mathrm{NI}_{\text {it }}=$ Net income of company in the period of $\mathrm{t}$

$\mathrm{CFO}_{\text {it }}=$ Cash flow operations of company in the period of $t$

$\mathrm{A}_{\mathrm{it}-1}=$ Total asset of company $\mathrm{i}$ in the period of $\mathrm{t}-1$

$\triangle$ SALES $=$ sales changing of company $i$ in the period of $t$

$\Delta \mathrm{AR}=$ account receivables changing of company $i$ in the period of $t$

$\mathrm{PPE}_{\mathrm{it}}=$ Property, plant, and equipment of company $\mathrm{i}$ in the period of $\mathrm{t}$

e $\quad$ Component of error

\section{Leverage}

Measurement of leverage uses theRatio Debt to Total Assets (DTA) (Dewi \& Fenny, 2011; Aryani, 2011; Jao \& Pagalung, 2011)

$$
\text { DTA }=\frac{\text { Total of Liability }}{\text { Total of Assets }}
$$

\section{Company Size}

Company Size was measured using natural log of net sales (Dewi and Fenny, 2011).

$$
\mathrm{UP}=\mathrm{Ln}(\mathrm{TNS})
$$

\section{Tax Planning}

Tax Planning was measured using tax retention rate, by dividing net income with earnings before interest and tax (Aditama \& Purwaningsih, 2013).

$$
\mathrm{TRR}=\frac{\text { Net Income }_{\text {it }}}{\text { EBIT }_{\text {it }}}
$$

\section{Technique of Analysis}

Equation of logisticregression:

$$
\begin{aligned}
\operatorname{Ln} \frac{E M}{1-E M}=\alpha & +\beta_{1} C_{A P T}+\beta_{2} D_{i t} \\
& +\beta_{3} L E V+\beta_{4} \operatorname{SIZE}+\beta_{5} \text { TRR }
\end{aligned}
$$

Explanation:

Ln EM/(1-EM) = Dummy Variable.

$$
\begin{aligned}
& \text { a = Constanta } \\
& \beta=\text { Coefficient of independent } \\
& \text { variable } \\
& \text { CAPT_it }=\text { Reserve of deferred tax assets } \\
& \text { of com pany in the period of } t \\
& \text { DA_it = Discretionary accrual of com } \\
& \text { pany in the period of } t \\
& \text { LEV = Leverage } \\
& \text { SIZE = Company Size } \\
& \text { TRR = Tax retention rate } \\
& \text { e }=\text { Component of error }
\end{aligned}
$$

\section{RESULT AND DISCUSSION}

Based on a sampling technique by purposive sampling, as many as 208 research observations obtained with the percentage of completion $100 \%$. From those 208 observations, there are 147 observations do earnings management, while the remaining 61 observations does not do earnings management

Descriptive statistics for variable of deferred tax assets, discretionary accrual, leverage, 
company size and tax planning in the company that do earnings management are explained as follows. Variable of deferred tax assets has a mean of 0,057 and standard deviation is 0,434 , minimum value is 3,523 and maximum value is 0,838 . Variable of discretionary accrual has average value of 0,099 with standard deviation is 0,775 , minimum value is $-2,607$ and maximum value is 2,910 . Both variables has higher standard deviation comparing to mean value. This condition describes that variable of deferred tax assets and discretionary accrual is various.

Variable of leverage has an average value of 0.413 and a standard deviation of 0.213 , minimum value of 0,037 dan maximum value of 1,049 . Variable of company size has a mean of 28.244 with a standard deviation of 1.882 , minimum value of 24.640 and a maximum value of 32.898. Variable of tax planning has an average value of 0.894 with a standard deviation of 0.560 , the minimum value of 0,504 and a maximum value of 5.513. All three of these variables have a standard deviation lower than the mean value. This condition shows that the leverage, company size and tax planning does not vary.
Descriptive statistics for the variable of deferred tax assets, discretionary accrual, leverage, company size, and tax planning that no action earnings management are explained as follows. Variable of deferred tax assets has an average of 0.182 with a standard deviation of 0.324 , minimum value is $-0,892$ and maximum value is 0.979 . Variable of discretionary accrual has an average value of 0,053 with a standard deviation of 0.766 , minimum value is $-1,869$ and maximum value is 2.316

Leverage has an average value of 0.533 and a standard deviation of 0.237 , minimum value is 0.128 and a maximum value is 0.975 . Variable of company size have an average value of 27.686 with a standard deviation of 1.698 , minimum value is 23.920 and a maximum value is 31.523 . Variable of tax planning has a mean of -0.775 with a standard deviation of 0.284 , minimum value is 0,092 and maximum value of 2.045.

Same with the conditions on companies that do earnings management, the variable of deferred tax assets and discretionary accrual very varied. Conversely the variable of leverage, company size and tax planning relatively varied.

Table 1. Descriptive Statistics for Company doing Earning Management

\begin{tabular}{lrrrrr}
\hline & \multicolumn{1}{c}{ N } & \multicolumn{1}{c}{ Minimum } & Maximum & \multicolumn{1}{c}{ Mean } & Std. Deviation \\
\hline APT & 147 & $-3,52$ &, 83 &, 05 &, 43 \\
DA & 147 & $-2,60$ & 2,91 &, 09 &, $77-$ \\
LEV & 147 &, 037 & 1,04 &, 41 &, $21-$ \\
SIZE & 147 & 24,64 & 32,89 & 28,24 & $1,88-$ \\
PP & 147 &, 50 & 5,51 &, 89 &, $56-$ \\
Valid & 147 & & & & \\
\hline
\end{tabular}

Table 2. Descriptive Statistics for Company not doing Earning Management

\begin{tabular}{llrrrr}
\hline & N & \multicolumn{1}{c}{ Minimum } & Maximum & \multicolumn{1}{c}{ Mean } & Std. Deviation \\
\hline APT & 61 &,- 89 &, 97949 &, 18 &, 32 \\
DA & 61 & $-1,86$ & 2,31638 &, 05 &, 76 \\
LEV & 61 &, 12 &, 97583 &, 53 &, 23 \\
SIZE & 61 & 23,92 & 31,52343 & 27,68 & 1,69 \\
PP & 61 &, 092 & 2,04530 &, 77 &, 28 \\
Valid & 61 & & & & \\
\hline
\end{tabular}


Jacobus Widiatmoko \& Ika Mayangsari / The Impact of Deferred Tax Assets...

$\mathrm{Ln}=-5.469-1.044 \mathrm{CAPT}-0.097 \mathrm{DA}-$

2.902 LEV + 0.246 SIZE + 1.195TRR + e

Based on the results of the logistic regression analysis, the variable deferred tax assets have a beta coefficient of -1.044 with a significance value of 0.059 is greater than 0.05 . It means that the deferred tax assets has negative effect and no significant effect on earnings management, so that $\mathrm{H} 1$ is rejected. There are several possibilities that can be used as a reason for management did not use the deferred tax assets as a tool for profit management. First, the management does not take advantage of the opportunity to determine the value of deferred tax assets at the end of each reporting period set forth in SFAS No. 46 in 2012 because it can harm the company when it was revealed that the management has manipulated earning value due to suspicion of the fiscal. Second, earnings management practices by management has been discovered by internal and external auditors and will be revised before it is published. Result of this study are consistent with research conducted by the Dewi and Fenny (2011), Pindiharti (2011), as well as Suranggane (2007).

Variable of discretionary accrual has a beta coefficient of -0.097 with a significance value of 0.651 . It is greater than 0.05 . This means that the accrual discretionary variables have a negative effect and no significant effect on earnings management, so that $\mathrm{H} 2$ is rejected. Discretionary accruals that have a negative impact on earnings management indicates that the greater discretionary accrual, the smaller the probability of the company earning management. This is because today companies are starting to realize the importance of presenting the financial statements more informative and accurate, so that the degree of probability of earnings management practices will decrease. The results are consistent with research Suranggane (2007), Cohen et al (2008), Widiastuti and Chusniah (2011), Linck et al (2013)

Variable of leverage has a beta coefficient of -2.902 to 0.000 with significance value less than 0.05 . These results indicate that leverage has negative and significant effect on earnings management, so $\mathrm{H} 3$ is rejected. Leverage that negatively affect earnings management indicates that the higher the leverage, the smaller the probability of the company earning management. Companies with high leverage level due to the amount of total debt to total assets will face a high default risk, which the company cannot meet its obligations. Earnings management cannot be used as a mechanism to avoid a default, because if earnings management practices are not interesting enough response to investor and creditor, the company must still fulfill its obli-

Table 3. Logistic Regression

\begin{tabular}{|c|c|c|c|c|c|}
\hline Variable & $\beta$ & S.E & Wald & Df & Sig. \\
\hline $\mathrm{APT}$ & $-1,044$ & 552 & 3,574 & 1 & 059 \\
\hline DA &,- 097 & ,214 & ,205 & 1 & ,651 \\
\hline LEV & $-2,902$ & ,752 & 14,892 & 1 & ,000 \\
\hline SIZE & ,246 & ,096 & 6,501 & 1 & ,011 \\
\hline $\mathrm{PP}$ & 1,195 & 691 & 2,988 & 1 & ,084 \\
\hline Constant & $-5,469$ & 2,656 & 4,240 & 1 & ,039 \\
\hline Chi Square & 4,894 & & & 1 & ,769 \\
\hline Cox and Snell R Square & ,131 & & & & \\
\hline NagelkerkeR Square & 187 & & & & \\
\hline$\alpha$ & 005 & & & & \\
\hline
\end{tabular}

Variable(s) entered on step 1: APT, DA, LEV, SIZE, PP. 
gations. The results are consistent with Abiprayu and Pangestuti (2011), Jao and Pagalung (2011), Dewi and Fenny (2011).

Variable of size has a positive and significant impact on earnings management, so $\mathrm{H} 4$ is accepted. This positive relationship between size and earnings management indicates that the greater the size of the company, the greater the probability of the company doing earning management. This can be explained by The Political Cost Hypothesis in a positive accounting theory which states that the size of the company is used as a guideline the political costs would increase with the size and risk of the company (Watts \& Zimmerman, 1986). The company's performance will be a major public and government concern, so that a larger company would be likely to make earnings management by reducing the current period income in order to avoid the high political costs. The result of this study are consistent with Dewi and Fenny (2011).

Variable of tax planning has a beta coefficient of 1.195 with a significance value of 0.084 . It is greater than 0.05 . These results indicates that the tax planning has a positive impact and no significant effect on earnings management, $\mathrm{H} 5$ is rejected. This positive relationship between tax planning with earnings management shows that the greater tax planning, the greater of earnings management practices. Insignificant value describes their weak influence between the variable of tax planning to earnings management. This may be due to more strict tax regulations, so the tax planning that made by the company less effective to minimize taxes in order to increase profits. The results of this study are consistent with Subagyo and Oktavia (2010), Ulfah (2013), Aditama and Purwaningsih (2013).

\section{CONCLUSION AND RECOMMENDATION}

Deferred tax assets have negative and no significant effect on earnings management. This is because that management did not take the opportunity from the policy under SFAS No. 46 in
2012. Discretionary accruals has a negative and no significant effect on earnings management. This is because that today companies are starting to realize the importance of presenting the financial statements more informative and accurate. Leverage has negative and significant effect on earnings management. This is because that earnings management practices cannot be used to avoid the risk of default.

Company size has positive and significant effect on earnings management. This is because that the performance of large companies will become public and government attention. Tax planning has positive and significant effect on earnings management. This is due to the stricter tax regulations. Future research is also expected to extend the period of observation in order to obtain the consistency of the results and can see the trend likelihood of earnings management. In addition, it is necessary to do research on companies from other types of industry as the research object, so it can look at the trends in the company's earnings management practices in general. Earnings management in this study only used the method profit distribution approach. Future research could use a different proxy measure of management in the probability of doing earning management.

\section{REFERENCES}

Abiprayu, K.B \& Pangestuti, I.R.D. 2011. Pengaruh Profitabilitas, Ukuran Perusahaan, Financial Leverage, Kualitas Audit, Dan Dividend Payout Ratio Terhadap Perataan Laba (Studi Kasus Pada Perusahaan Manufaktur Yang Terdaftar Di Bursa Efek Indonesia Tahun 2006-2009). Universitas Diponegoro.

Aditama, F \& Purwaningsih, A. 2013. Pengaruh Perencanaan Pajak terhadap Manajemen Laba pada Perusahaan Nonmanufaktur yang Terdaftar di Bursa Efek Indonesia. Jurnal Ilmiah Akuntansi. 1 (15).

Aryani, D. S. 2011. Manajemen Laba pada Perusahaan Manufaktur di Bursa Efek Indonesia. Jurnal Ekonomi dan Informasi Akuntansi. 1(2).

Belkaoui, A. R. 2007. Accounting Theory. Jakarta: Salemba Empat. 
Jacobus Widiatmoko \& Ika Mayangsari / The Impact of Deferred Tax Assets...

Cohen, D.A., Dey, A \& Lys, T.Z. 2008. Real and Accrual Based Earnings Management in the Pre and Post Sarbanes Oxley Periods. The Accounting Review. 83(3): 757-787.

Dewi, S. P \& Fenny. 2011. Pengaruh Aset Pajak Tangguhan, Diskresioner Akrual, Tingkat Hutang, dan Ukuran Perusahaan terhadap Manajemen Laba pada Perusahaan Manufaktur yang Terdaftar di Bursa Efek Indonesia. Jurnal Asy-Syukriyyah. 7: 1-29

Field, T.D., Thomas Z.L \& Vincent, L. 2001.Empirical Research on Accounting Choice. Journal of Accounting and Economics. 31(1): 255-307.

Han, J.C. Y \& Wong, S. 1998. Political Costs and Earning Management of Oil Companies During the 1990 Persian Gulf Crisis. The Accounting Review. 73 (1): 103-117.

Iatridis, G. E. 2012. Audit Quality In Common-Law And Code-Law Emerging Markets: Evidence On Earnings Conservatism, Agency Costs And Cost Of Equity. Emerging Markets Review. 13(2): 101-117.

Jao, R \& Pagalung, G. 2011. Corporate Governance, Ukuran Perusahaan, dan Leverage terhadap Manajemen Laba Perusahaan Manufaktur Indonesia. Jurnal Akuntansi dan Auditing. 8 (1): 43-54.

Jones, J. 1991. Earning Management During Import Relief Investigations. Journal of Accounting Research. 29 (2): 193-228.

Linck, J.S., Netter, J \& Shu, T. 2013. Can Managers Use Discretionary Accruals to Ease Financial Constraints? Evidence from Discretionary Accruals Prior to Investment. The Accounting Review. 88(6): 2117-2143.

Mao, Y \& Renneboog, L. 2015. Do Managers Manipulate Earnings Prior To Management Buyouts ?. Journal of Corporate Finance. 35.

Philips, J., Pincus, M \& Rego, S. O. 2013. Earnings Management: New Evidence Based on Deferred Tax Expense. The Accounting Review. 78(2): 491-521.

Pindiharti, D. 2011. Pengaruh Aktiva Pajak Tangguhan, Beban Pajak Tangguhan dan Akrual terhadap Earning Management: Studi Empiris pada Perusahaan Manufaktur di Bursa Efek Indonesia. Fakultas Ekonomi dan Bisnis.
Universitas Islam Negeri Syarif Hidayatullah.

Riantani, S \& Nurzamzam, H. 2015. Analysis of Company Size, Financial Leverage, Profitability and Its Effect to CSR Disclosure. Jurnal Dinamika Manajemen (Journal of Management Dynamics). 6(2): 200-210.

Suandy, E. 2013. Perencanaan Pajak. Jakarta: Salemba Empat.

Subagyo \& Oktavia. 2010. Manajemen Laba sebagai Respon atas Perubahan Tarif Pajak Penghasilan Badan di Indonesia. Simposium Nasional Akuntansi XIII.

Subagyo, Oktavia, \& Marianna. 2011. Pengaruh Discretionary Accrual dan Beban Pajak Tangguhan terhadap Manajemen Laba. Jurnal Akuntansi. $11(1)$.

Suranggane, Z. 2007. Analisis Aktiva Pajak Tangguhan dan Akrual sebagai Prediktor Manajemen Laba : Kajian Empiris pada Perusahaan Manufaktur yang Terdaftar di BEJ. Jurnal Akuntansi dan Keuangan Indonesia. 4 (1): 77 94.

Ulfah, Y. 2013. Pengaruh Beban Pajak Tangguhan dan Perencanaan Pajak terhadap Praktik Manajemen Laba. Prosiding Simposium Nasional Perpajakan 4.

Watts, R. L \& Zimmerman, J.L. 1986. Positive Accounting Theory. New Jersey : Prentice-Hall, Inc.

Widiastuti, N. P E \& Chusniah, E. 2011. Analisis Aktiva Pajak Tangguhan dan Discretionary Accrual sebagai Prediktor Manajemen Laba pada Perusahaan yang Terdaftar di BEI. Jurnal Econosains. 9 (1): 28-40

Wu, S., Chen, C \& Lee, P. 2016. North American Journal of Economics and Finance Independent directors and earnings management : The moderating effects of controlling shareholders and the divergence of cash-flow and control rights. North American Journal of Economics and Finance. 35: 153-165.

Xie, B., Davidson, W.N \& DaDalt, P.J. 2003. Earnings management and corporate governance: the role of the board and the audit committee. Journal of Corporate Finance. 9(3): 295-316. 